\title{
ALDH1B1 wt Allele
}

National Cancer Institute

\section{Source}

National Cancer Institute. ALDH1B1 wt Allele. NCI Thesaurus. Code C97218.

Human ALDH1B1 wild-type allele is located in the vicinity of 9p11.1 and is approximately 6 $\mathrm{kb}$ in length. This allele, which encodes aldehyde dehydrog enase $\mathrm{X}$, mitochondrial protein, plays a role in the modulation of alcohol-derived acetaldehyde metabolism. 